\title{
Videoing supervision: Messages for probation practice
}

Rachel Goldhill, University of Portsmouth 


\section{Abstract}

This paper reports on a PhD study, investigating the supervision of women service users (WSUs), by women probation officers (POs) based on video data of one-to-one supervision sessions. The research identifies competing agendas of probation in England and Wales - one side emphasises punishment, whilst the other encourages humanistic, relationship-based practices. POs, routinely juggling these opposing expectations, appreciate traditional probation values of giving the WSU a voice and embracing psychodynamic approaches, to provide structure and support in confronting the complexities of officer/service user interactions. However, the data show that driven by managerialist enforcement requirements, it is the punitive discourse which is more frequently translated into practice. Organisational pressures, feelings about the person opposite, the offence or the individual's background can manifest as conscious or unconscious micro-messages or masking messages. Just as SUs put on masks to disguise negative emotions or feel powerful, so too do POs; POs recognise masks and deceptions in SUs and, similarly, SUs are aware of this dynamic with POs. The research identifies practitioner ambivalence to certain narratives, particularly sexual abuse or poor mental health and, it is argued, reflective supervision is needed to deconstruct difficult personal and professional issues.

Keywords: probation officer, woman service user, humanistic relationship-based practice, punitiveness

\section{Introduction}

The concepts and procedures in this article originate in research for a PhD study on probation work with women service users; this project was set up to observe practice unobtrusively. Most research projects employ interviews and questionnaires, asking practitioners about their modus operandi, whereas videoing enables inspection of real-life interaction, with observable verbal and body language, rather than relying on participants' impressions. The methodology section describes the exclusively qualitative approaches used for the study. The essence of a positive relationship with 
service users is considered, one which promotes engagement because, without this foundation, little can be achieved. Feedback from WSUs is shown in regard to their feelings about their PO and what they found to be helpful but, for a number of reasons, individuals are not always honest about their feelings, either striving to protect people who have shown kindness to them, or hostile because of poor past experiences with authority figures. So, the research, explores what takes place in the relationship through direct observation of conversations. Probation workers experience pressures to adopt opposing approaches and discourses. On one hand, is a correctionalist, risk and target-driven 'one size fits all' agenda, deriving initially from the raft of legislation and policies in England and Wales under the New Labour government and more recently from the Transforming Rehabilitation (TR) agenda. The other way of probation working, stems from the social work tradition, consisting of constructive, strengths- and relationship-based, individualised methods. This research shows that POs may believe they are acting in a positive way but, for a variety of reasons, their practice produces negative messages (Trotter, 1999: 76). The analysis reveals that POs miss opportunities to confront problems in supervision when they are experiencing strong negative feelings themselves around areas such as sexual abuse or where the service user is a perpetrator and/or a survivor and where trauma and mental health issues are present. It is argued that managerialist discourses enable POs to demonstrate that the Order/Licence has been enforced; but compliance will be on a superficial basis rather than confronting the deep-seated problem. All the POs in this sample were female and, although this was not by design, gender issues are considered significant.

\section{The political context of the research}

The project covers the period immediately preceding the implementation of TR (2011-2015); this initiative, driven by Chris Grayling, Secretary of State for Justice in the Coalition Government, came into force in England and Wales in February 2015. The probation service was split into two with $30 \%$ remaining a public service organisation, part of the Civil Service, as the National Probation Service (NPS) and 70\% outsourced to private Community Rehabilitation Companies (CRCs). Deering and Feilzer's (2015) study of practitioners' views on moves to privatise the 
probation service, indicated that the core fabric of humanistic values was threatened. In the runup to this major organisational change significant resistance was shown, specifically from the probation union, the National Association for Probation Officers (NAPO), representing mostly main-grade workers. Throughout the process staff had serious worries that reorganisation would result in worse pay and conditions (Deering and Feilzer, 2015). Concerns were also raised by academic commentators, the Probation Chiefs Association and the Inspectorate of Probation (2013) cited by Hedderman and Murphy (2015: 218). Instead of, as before, developing 'sophisticated understandings' of offenders' complex and disadvantaged lives with aims of change and empowerment, the post -TR world would be made up of staff merely ticking boxes (Fitzgibbon, 2013: 88).

Recent research indicates that these concerns were justified. Kirton and Guillaume's study (2015) outlines significant deterioration in NAPO's negotiating position with employers, upholding traditional values for practitioners and service users. 'Gender effects' are particularly pinpointed, citing less transparency around salaries, involving a widening pay gap and less opportunity to improve employment prospects. Consequences are increased workload and staff with caring responsibilities moved, against their will, to offices further from their home (Kirton and Guillaume, 2015: 13). Regular reports from the Probation Inspectorate, tracking the reorganisation, have highlighted implementation problems and deteriorating work standards (Webster, 2016). This has had a detrimental effect on supervision of WSUs, with less opportunity to focus on lower risk offenders (women's offences are predominantly low to medium risk and even those women in the NPS are often considered 'less risky' than their male counterparts); accompanying austerity budget cuts have led to fewer community resources available for vulnerable women (Walby, Towers and Francis, 2015). 


\section{Historical tensions between relationship-based and correctional practices}

Investigation of the type of interaction which promotes a constructive officer/service user relationship (Burnett and McNeill, 2005) underpins this study. Until the mid-90s probation training was situated in social work education, emphasising and integrating humanistic, relationship-based ideals. Governmental attempts were made to move away from this approach in the mid-1990s when Michael Howard, Home Secretary, permanently stopped the social work qualification and efforts were made to attract ex-armed services personnel to give the profession a correctional image and to employ more male practitioners (Raynor and Vanstone, 2007: 68). These endeavours were largely unsuccessful and probation stayed predominantly female. From the late 1990s humanistic approaches were diminished further with the introduction of the prescribed processes of What Works and cognitive behavioural, standardised groupwork programmes (NPS, 2001). What Works paid lip service to the relational base, but its focus was predominantly on risk, punitiveness and managerialism (Farrant, 2006), overshadowing psychodynamic approaches - 'risk undermines rehabilitation, imposes a surveillance framework on people and services, draws resources away from therapeutic and rehabilitative programs' (Sheehan, 2014: 63). Probation has been obliged to prove to successive governments that it offers credible punishment and safeguards for risk of serious harm and reoffending. The correctionalist discourse, epitomised by the Carter Review and Criminal Justice Act, 2003, was developed by New Labour as a political vote-winning tactic to alert the public and media that they were taking a tough stance (Raynor and Vanstone, 2007: 77).

Notwithstanding this, many individual officers continued to believe that the officer/service user relationship was the basis for productive work (Annison, Eadie and Knight, 2009). From 2010 onwards the offender engagement programme (OEP) (Ministry of Justice (MoJ), 2011) and Skills for Effective Engagement and Development (SEEDS) pilots were set up in the majority of UK probation areas (Sorsby, Shapland, Farrall, McNeill, Priede and Robinson, 2013), modifying a punitive and rigid organisational culture. An increased re-acknowledgement and re-emphasis on desistance processes was introduced. The inclusion of 're' is intentional and important to note because these humanistic aims have been the bedrock of probation practice (Nellis, 2007; Annison, Eadie and 
Knight, 2008; Canton, 2011). In addition, recognition of attachment (Ansbro, 2008) and trauma issues (Covington, 2008) contributed to greater understanding and tolerance of 'problematic' clients in terms of mental health issues, particularly personality disorder, depression and anxiety. Attachment knowledge around the 'secure base' in childhood, indicates a need for continuity in the practitioner/service user relationship - 'the more disturbed the...person, the more important it is for them to avoid having attachments ruptured' (Ansbro, 2008: 240). Inconsistency and fragmentation may mean that childhood experiences of abusive or neglectful parenting, contributing to dysfunctional and chaotic lifestyles in adulthood (Willis and Levenson (2016)), are replayed or played out within probation supervision. With the 'run up' to TR, relationship-based leanings were once again largely discarded - 'insufficient steps were taken to overcome barriers to engagement in delivering the sentence.' (HM Inspectorate, 2016: 18).

Mawby and Worrall (2011) refer to probation agencies' increased 'feminisation' insofar as, at all levels, more women than men work within the organisation. The inference from this 'feminised' label is of softer, caring, relational ways of operating rather than 'harder' public protection pathways embodied by other agencies in the criminal justice system. Yet power and dominance in the Service are still strongly connected to punitive practices and discourses because probation needs to appear a plausible option for the (essentially male occupations) of the courts and police and probation's own employer, the National Offender Management Service (NOMS) which incorporates the prison service. Of course, both discourses may have significant and necessary places, specifically for individuals who have lacked boundaries and consistency throughout their lives and who continue to cause harm to others. However, it is argued here that pressure from the organisation more often skews interventions towards punishment, not for the benefit of the individual, but for probation to justify and enable its existence in an increasingly harsh political climate. POs may adopt more intransigent and punitive stances, attaching themselves to the organisational power structures in order to progress up the career ladder and demonstrate efficiency as a practitioner. Other research supports this supposition. Huppatz's (2012: 110) study of gendered occupations, exemplified by social work and nursing, both of which share significant commonalities with probation, reveals 
ongoing gender discrimination in management structures. Huppatz argues that for main grade workers in these professions, looking for promotion, more pressure is felt by women than men to prove themselves, through supporting severe and rigid approaches. Ostermann and Comunello da Costa (2012: 206) found that, ironically, Brazilian policewomen gained gravitas in the eyes of senior colleagues by aligning themselves with the institution's dominant (sexist and racist) ideology.

Whether male or female, POs have personal leanings towards punitive or humanistic ways of operating, for a number of other reasons. Diversity issues are influential, where a service user appears similar/different to the PO in terms of age, gender, ethnicity or background or values. POs may also hold strong negative attitudes towards the type of offence committed, adopting a stricter position towards sex offenders and domestic violence (DV) perpetrators. Whereas it is widely known and accepted that female DV and violent offenders have often suffered years of various types of victimisation (Henning, Jones and Holdford, 2003; Batchelor, 2005; Pollack, 2007; Hester, 2013), female sex offenders are more likely to be seen as unnatural or doubly deviant (Heidensohn and Silvestri, 2012:351). Having transgressed gender expectations as well as committing a serious offence, they could receive a less sympathetic response. Even when a purposeful relationship is acknowledged theoretically as beneficial, the end result may still be disengagement, resentment and head-on collisions.

\section{Methodology}

Three interlinking methods underpinned the collection of qualitative data. Initially an ethnographic approach was adopted whereby time was spent in a 'natural setting' observing communications between POs and WSUs and participant observation in probation offices, at meetings and on home visits. The videoing of one-to-one supervision sessions of 10 pairings of POs/WSUs took place on three occasions, a few weeks or months apart; this involved the PO speaking with the WSU about the goals for their Community Order (CO) or Licence and how they could be achieved. A fixed camcorder was set up in the interview room, without the researcher present. Semi-structured 
interviews took place with the women and the POs separately. A male PO and a woman PO who had previously set up an award-winning women's programme were interviewed as well as the facilitators of a woman's specified activity requirement (SAR). All data were processed after transcription, using thematic and discourse analysis. The sample size is small and generalisations cannot be taken from it but findings draw attention to aspects of probation practice, which may in the normal way be glossed over, suggesting areas to investigate in relational supervision. In this paper the focus is on one particular supervision as an illustration of the tensions between the different discourses which were present throughout the whole data set. Since the Corston Review (2007) it has been generally acknowledged that there are different pathways to offending for men and women and specific reactions to certain women service users are commented on. This paper focuses on those probation officers in the study who were working with individuals who had caused high risk of harm and have complex needs.

\section{The Study}

One of the principle aims of probation work is service user engagement through the relationship. In the study, much of the data show women highly appreciative of their POs, displaying loyalty and gratitude for the time and effort that POs had put into their meetings; features of prosocial modelling (PSM) are evidenced throughout the data. PSM is defined by Cherry (2005: 3) as exhibiting 'a genuine concern for the person and, persistence and optimism about their capacity to change, clear explanations about values, roles and expectations and negotiating ways forward'. These attributes are visible in the following feedback narratives of WSUs, Siobhan, Laura and Sonya ${ }^{1}$. The women were responding to open questions about their time under current probation supervision and comparisons with their former experiences.

\footnotetext{
${ }^{1}$ All names and places are anonymised.
} 
1) Siobhan, an 18 year old white woman, bottled another young woman in a night club, having consumed large amounts of alcohol. During her adolescence she was out of control, living in Manchester with her alcoholic and epileptic father and had received Supervision Orders with the Young Offender Team (YOT). Subsequently she returned to her birthplace, a small town in the south of England, living alone in a small rented flat near to her mother and step-father. Whilst on supervision with Di she was intent on obtaining a job, getting fit through swimming and cutting down on her drinking.

Di's better than they were, like she understands. They [YOT] were just doing their job cos they had to sort of thing. I was telling them, this isn't helping me. I'm going to break things again...and I did. They didn't really help a lot. Di listens to me and anything I say to her, she'll try to sort it out for me...she knows all about my life history.

2) Laura is a white woman in her late 40 s. She had been a full-time carer for her 2 sons (both of whom had learning disabilities) and taken to drinking heavily in the evenings. One evening during a family dinner, when she, her husband and her husband's mother had been drinking heavily she stabbed her husband, causing near fatal wounds. She received a Suspended Sentence Order with a supervision requirement. Her presentence report, written by Susan, (PO), with the case then taken over by a probation service officer (PSO), Fi but returned to Susan in the later stages of her Order because of the TR reorganisation.

...she sat and listened intently, took down everything that I said without any discrimination, no judgement or anything. So I felt secure (Laura, WSU, about her PSR with Susan, PO).

I am still very ashamed of what I did and it really does upset me what I did because that's not me clearly and erm they turned it around and said it isn't all your fault. And I said he didn't mean to and he probably, he didn't mean to make me feel like that. But did he? And there was a sort of balance and they managed to turn my whole way of thinking - not, yes he deserved it but actually it was a build-up over years and years that affected me and I took to the bottle because there was no-one to help me.

I think paramountly they have to make sure that I'm behaving myself which I'm now over-behaving myself I don't do anything wrong. Um but I think their goal was to, like Fi [PSO] said in the early days they were there to help me, don't worry you're not in any trouble, you're not going to prison. We're here to help you, that's what she said and I thought, like I said that POs were just there to rap you on the knuckles for being a bad person, sign the book and off you go till the next time. I didn't know that they spoke to you, I didn't know that they become almost, I know you shouldn't use that word emotionally attached because I could talk about my sons ...- so you build up a friendship. So I think their role was to keep me on the straight and narrow, to make sure I completed what the Judge given me but also to listen to me, to listen to how I was feeling and obviously they're trained to see whether I'm going to re-offend or whatever. 


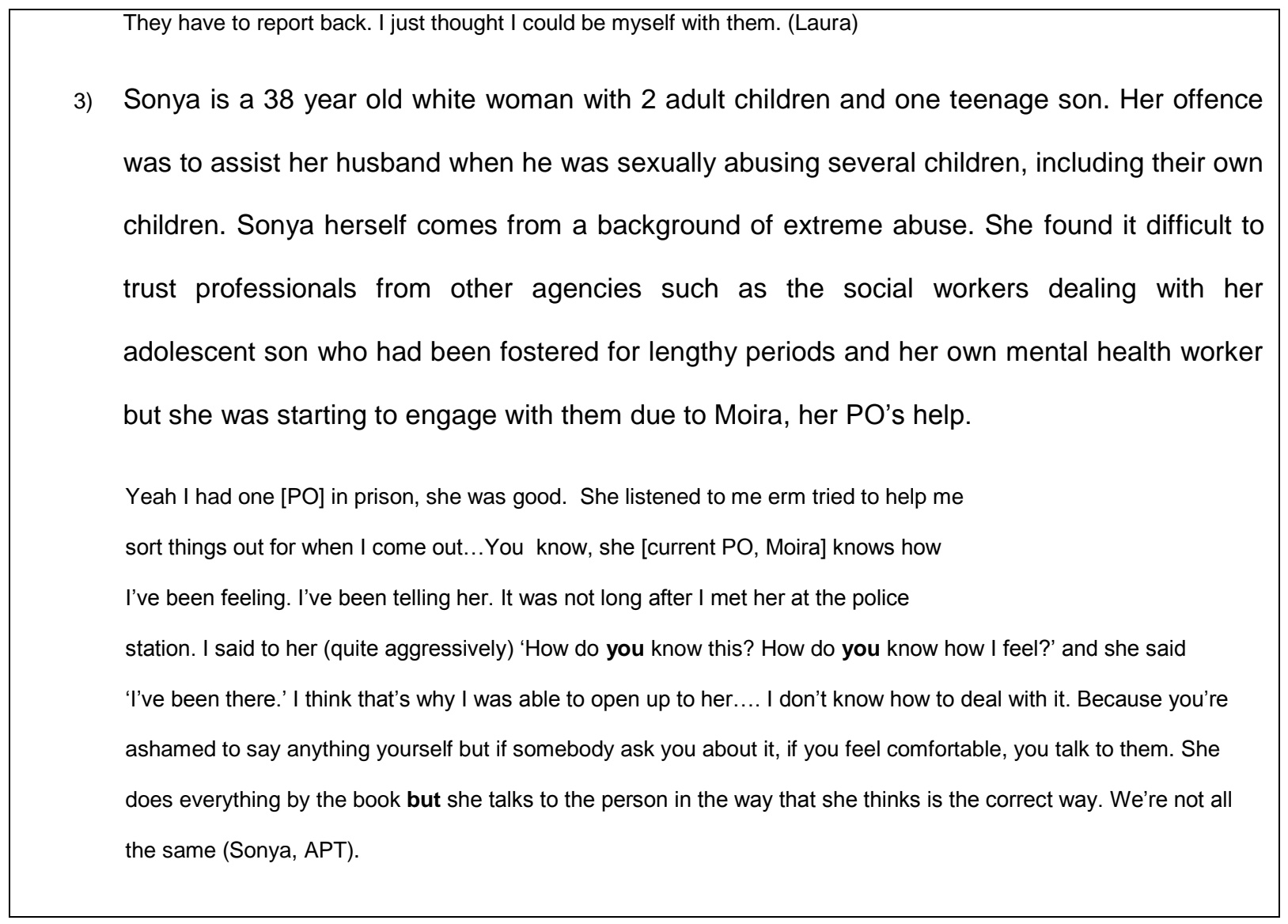

Discussions with these service users represent positive messages of what they value - abilities to listen, reliability, boundary-setting, showing an interest, caring, being consistent, sharing appropriately and giving sound advice.

Other parts of the transcripts in my data aligned more closely with Cherry's (2005: 127-8) notion of 'micro-messages', which are forms of communication, 'often unintentional and often unnoticed' (Cherry, 2005: 127-8) yet, nevertheless, demeaning to service users, promoting disengagement and provoking resentment. These interchanges can occur in verbal and body language, initiating inequalities and placing already disempowered individuals at still greater disadvantage. Such messages are hard to identify and confront because they are often masked by a smile or a friendly facade. Just as service users put on masks to disguise negative feelings towards the other person or to feel powerful POs, on occasions, do exactly the same. In the same way that service users' insincerity and deception are apparent to probation practitioners, so too can service users sense an underlying hostility from POs. Discourse analysis (DA) has been undertaken for this investigation 
into everyday conversations, enabling an 'understanding of social interaction....and communication' (Wooffitt, 2005: 1). Transcripts are examined with a focus on exploring the power imbalances. The following excerpt is taken from the research data; it has already been shared in presentations to newly qualified POs (NQOs), women centre workers and academic psychology colleagues with some of the feedback included in the right hand column.

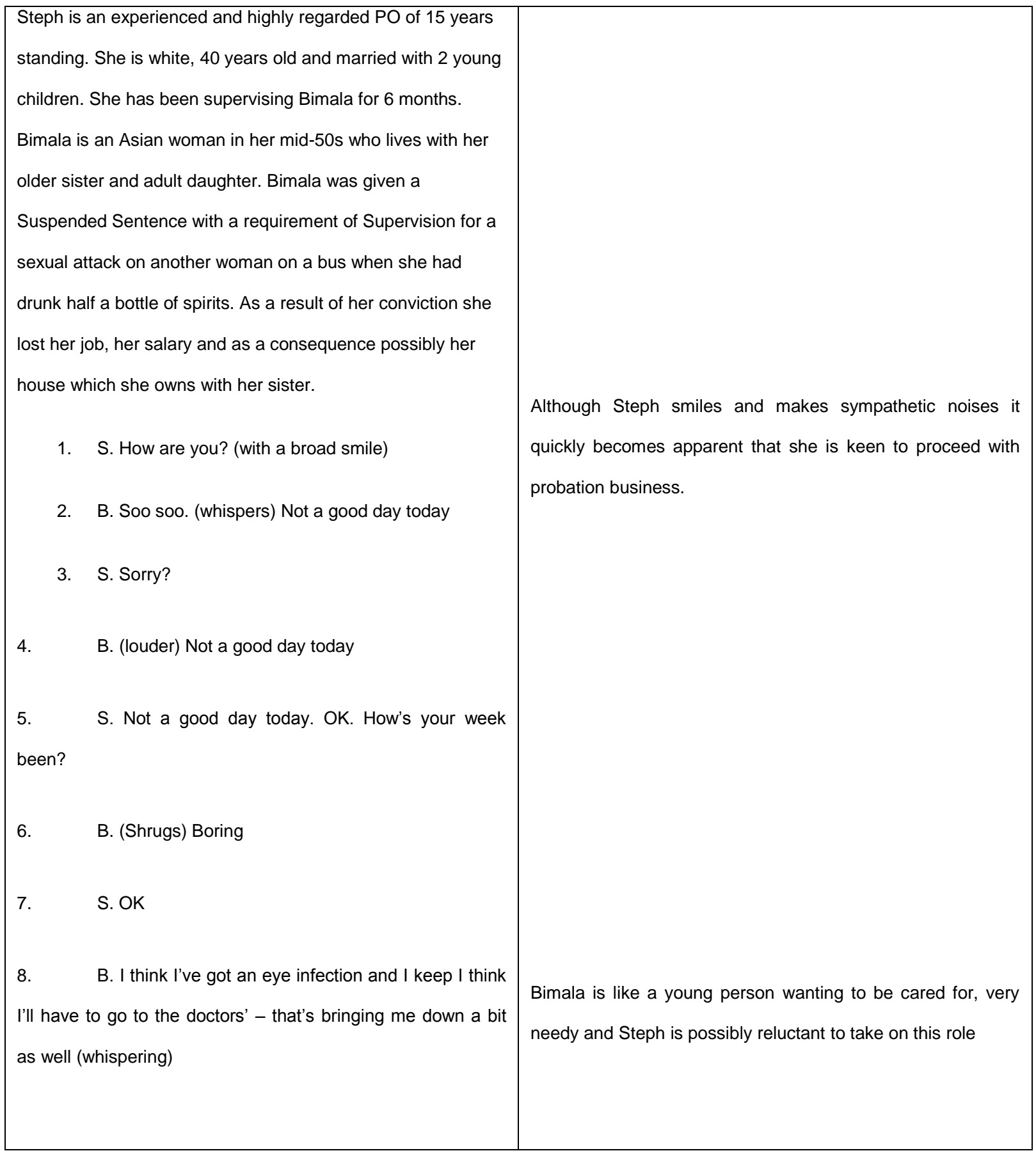




\begin{tabular}{|c|c|}
\hline 9. & S. Oh. Are they sore? \\
\hline 10. & B. They're itchy \\
\hline 11. & S. Oh dear. \\
\hline 12. & B. I'll have to make an appointment \\
\hline 13. & S. You can get drops from a pharmacy \\
\hline 14. & B. Yeah I'm going to go and try that \\
\hline
\end{tabular}

Steph does not fully acknowledge how bad Bimala is feeling and shows her impatience by offering practical suggestions and then changing the subject. This interruption has been viewed as a means for the practitioner to take control of the discussion thus preventing service users from conveying the full range of their anxieties ( $\mathrm{Li}$, Desroches, Yum, Koehn and Deagle, 2007: 421). By downplaying the problem there is no room for resolving the difficulties. Li et al (2007) argue that this is not only a personal infringement but also prevents the passing on of important information that would lead to improved understanding of the individual's position.

erm. Last week, do you remember last week?

Here Steph is very directive as she starts to reprimand Bimala for coming into the office drunk and as if she is being told off

16. B. (nods)

17. S. You do OK. Erm. I just wanted to remind you that you can't, you shouldn't report under the influence of alcohol and if you do again that could count as a missed appointment.

18. B. Yes OK certainly (looking down).

19. S. And you were going to phone me with your sister's number.

20. B. I don't want my sister involved in it. She's going through a lot at the moment. So all those things l've told you are just between me and you. And l'll just have to put up with it because she's had to put up with a lot... with me...that's the way I'm looking at it.

21. S. Erm OK. I guess that makes it difficult for you to achieve your sentence plan, doesn't it?

\section{B. I'm starting to cry already, I'm a bit down today}

23. S Oooh. (Reaches for tissues. Turns to get the tissues. Does not make eye contact). There's some tissues here, would you like a tissue?

Although Steph offers a sympathetic expression by producing 


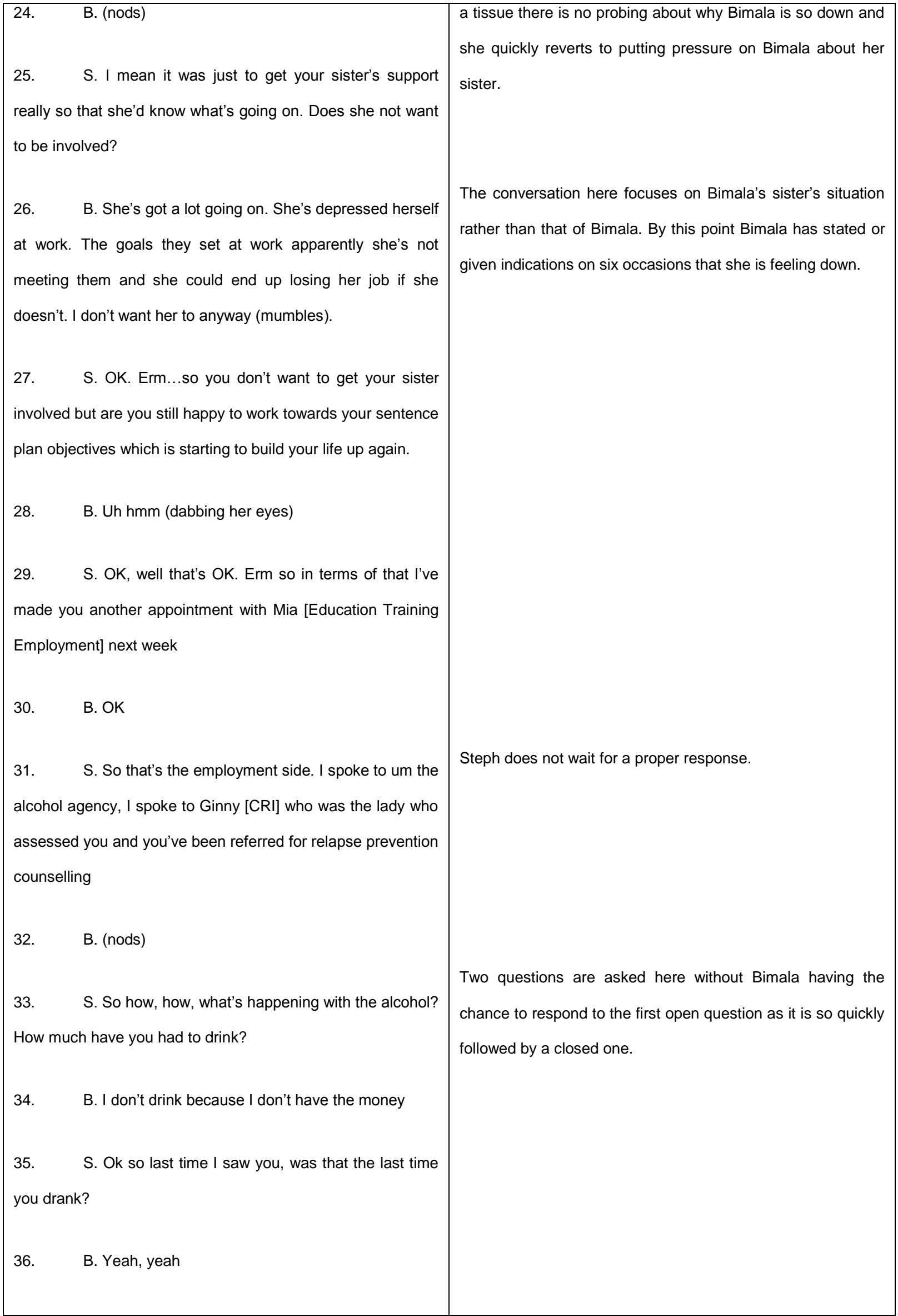




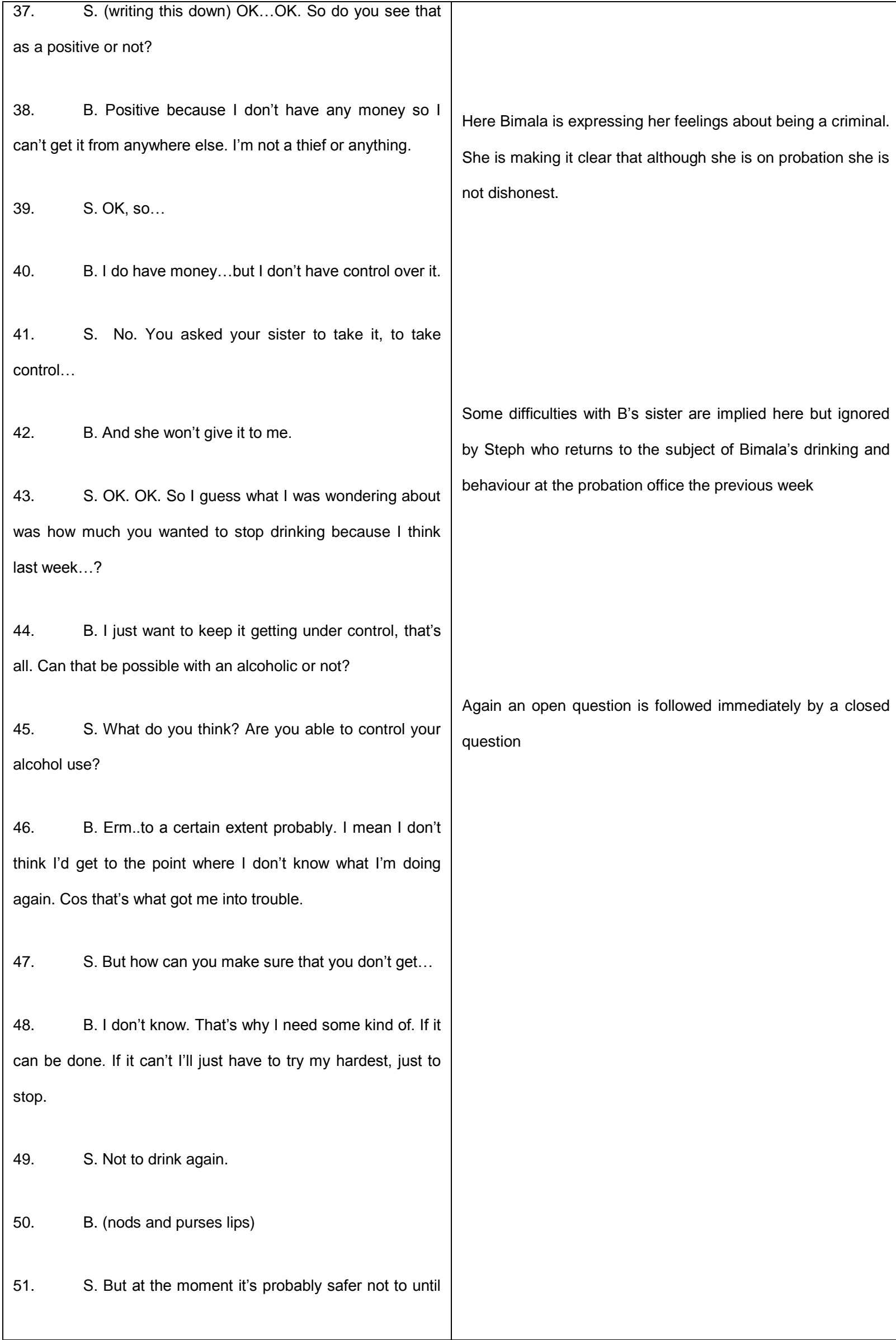




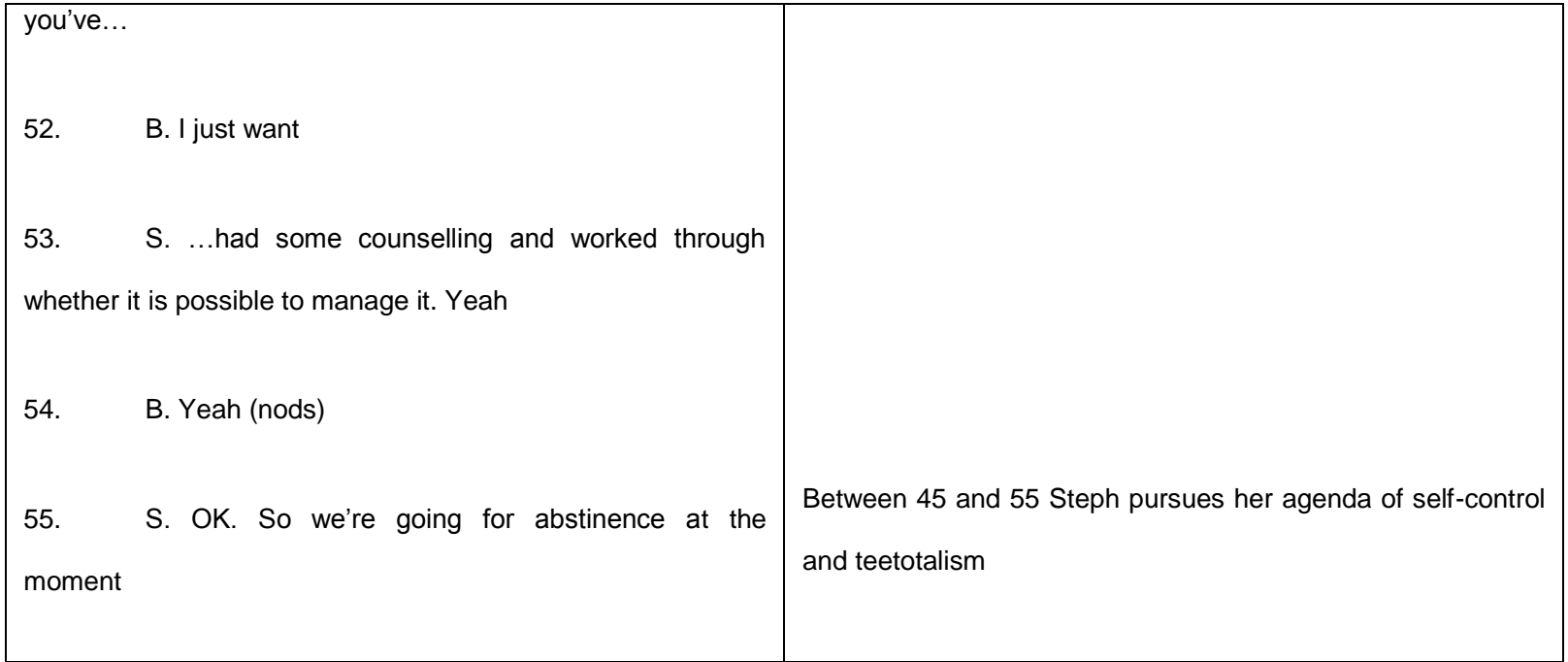

\section{Discussion}

In this supervision session Steph is carrying out a thorough, albeit somewhat overly structured, interview which Fitzgibbon (2007: 92) describes as 'non-transformative risk management'. Despite Steph's categorical concluding remark (line 55) it seems unlikely that the supervision session will have any effect in helping Bimala to refrain from drink. By showing her disapproval of Bimala's behaviour the previous week and ensuring that she checks the current state of her alcohol intake, Steph is carrying out a tick box exercise; she neither listens to Bimala's concerns nor engages with Bimala's feelings. After the first exchange (lines 1-14) Steph initiates all conversation, disallowing any displays of emotion. Ostermann and Comunello da Costa's (2012) research notes 'assessment turns' in responding to female survivors of DV, identifying how policewomen's communications used 'an economy of emotion' whereby victims' narratives were cut off, by interruption and changing the subject (McElhinny, 1993 cited by Ostermann and Communello da Costa, 2012). Social distance can also be established through politeness which can mask dislike and impatience (Ostermann and Communello da Costa, 2012: 207). Moreover, observations of doctor/patient interactions have shown that, compared to male patients, women were 'treated with less respect...not taken as seriously' and 'interrupted more frequently' (Li, Desroches, Yum, Koehn and Deagle, 2007: 422). Lewis (2014: 169) maintains that if respect is missing, which she defines as a lack of empathy, listening and support, 'a "toxic" environment' will be created whereby self-destructive behaviours are 
more likely and probationers lose faith, not only in the officer seeing them but with the organisation as a whole. It appears that as a result of Steph's attitude towards her, Bimala stops trying to say anything about herself, responds with monosyllabic words and gestures and sinks deeper into her hopelessness. Gilbert (2010) cited by Knight and Modi, (2014: 134) comments that 'A worker who is unable for whatever reasons, to "hear" such stories to offer...emotional containment and safety is likely to shut down the offender's tentative steps towards self-disclosure and understanding.' The 'significant adversity' female sex offenders have faced in their early life, connecting to 'multiple dysfunction as adults' is stressed by Willis and Levenson (2016: 10) who argue for 'a nurturing and supportive environment' to lead to 'more adaptive core beliefs'.

Clearly opportunities have been missed here and it is an area of speculation as to why this might be the case. When Bimala speaks about her eye problems (lines 8-14) she is asking for sympathy and possibly even mothering, sounding childlike and extremely needy. Campos, Mesquita, Besser and Blatt (2014) correlate depression with neediness and Bettles, Rich and Bourne (2015) comment on the irritation staff can feel when service users demonstrate such dependency, viewing it as making excessive demands on them. Many women service users have suffered from childhood sexual abuse or other trauma so it could be Steph is fearful that if she explores painful issues with Bimala she could stir up a 'can of worms' (Goldhill, 2015); so she chooses to protect not only Bimala but herself. Her dismissal of Bimala's comments about feeling down, infer a judgement that she does not want to be party to any 'wallowing' in depression. There seems too that a sense of resentment exists that Bimala has not cooperated with Steph's sentence plan. Emotions are not considered here as legitimate within probation work, despite Bimala having clearly experienced extensive recent loss in her life. The offence and her subsequent unemployment have led to insecurities about maintaining her accommodation and problems in her family relaitonships. All sorts of emotions, such as guilt and anxiety, may exacerbate her drinking. Had Steph taken a more compassionate and less superficial stance the underlying reasons for drinking would have been a valuable area to explore; this is necessary work with alcohol acting as a trigger to the offence. Two of the presentation groups (the NQOs and the psychologists) also raised the point that they saw Steph as 
feeling uncomfortable with Bimala's sexuality. Bimala's sexual offence was perpetrated against a younger woman when she was inebriated in a confined space (the bus) and this set-up is partially replicated in the small interview room where space dictates the two have to sit close to each other. Therefore it was thought that Steph may have felt she needed to keep a tight rein on proceedings. However for Steph it would have been taboo to name this feeling and similarly, any attraction on Bimala's side, could not be spoken out loud.

Speculation is useful only insomuch as it could offer Steph insights to how her feelings affect her behaviour. Of greater importance is what Steph feels is happening in this session and how she could use reflection to understand and stay with Bimala's difficulties. Ruch (2005: 118) argues that relationship-based holistic reflective practice enables practitioners to deal with unpredictable and disturbing contact which would be intensified by a non-supportive work environment. Ultimately only Steph can reveal how she experienced this unique encounter and work through the blocks to produce more constructive interventions.

\section{Conclusion}

Lack of time, large caseloads comprising individuals with complex problems and multiple agency reorganisations have dogged the probation service and its workers for at least 20 years and this study suggests that female POs may feel the impacts more keenly. This paper has argued that tensions exist between two well-established probation discourses. POs regularly have to manage opposing expectations on them, from the wider organisation of NOMS, with its connections to the Ministry of Justice and obligations to service users with entrenched problems. Where trust and respect towards an authority figure exists it enables reflection and support if there is a downward spiral in the person's life which can increase risk factors. Messages from the study are that POs need to acknowledge their aversions and anxieties around service users in order to be able to respond positively and appropriately, even where there are personally and societally confronting factors such as sexual abuse and mental illness. In addition administrative structures where the 
punitive discourse dominates, provide a setting where psycho-social and contextual issues, affecting the possibility of SUs' desistence, can easily be ignored. Prosocial modelling is a humanistic strategy that advocates involving the whole organisation in relationship-based practice; it is recommended as a basis for professional formal and reflective supervision (Cherry 2005: 153). Yet this type of supervision, encouraging practitioners to confront and deal with strong feelings, has slipped down the priority scale. If the interaction between officer and service user is to be truly valued then relational supervision, incorporating observations and feelings of both participants, should be actualised at every level of the agency. POs are not psychodynamic counsellors but behaviours have deep-seated reasons, going beyond offending behaviour and legal requirements. If not addressed, WSUs will remain vulnerable to further offending; they will have been punished but not rehabilitated. Successful probation work is more than a way of reaching out to somebody in trouble; it involves understanding the service user's holistic situation and, equally, the ability to help the WSU achieve understanding.

\section{References}

Annison J, Eadie T and Knight C. (2008) People first: Probation Officer perspectives on probation work. Probation Journal, 55(3): 259-271

Ansbro, M. (2008) Using Attachment Theory with Offenders. Probation Journal, 55, (3), 231-244. Batchelor, S. (2005) '" Prove Me the Bam!" Victimisation and Agency in the Lives of Young Women Who Commit Violent Offences'. Probation Journal 52 (4), pp. 358-375.

Bettles, S., Rich, B. and Bourne, R. (2015) Managing challenging residents. Putting the Knowledge and Understanding Framework (KUF) into practice in Approved premises. Probation Journal, December 28, 2015, doi:10.1177/0264550515620692

Burnett, R. \& McNeill, F. (2005) The place of the officer offender relationship in assisting offenders to desist from crime, Probation Journal, 52, (3), 221-242

Campos, RC, Mesquita, I, Besser, A. and Blatt, SJ (2014) Neediness and depression in women. Bull Meninger Clin., 78 (1) 16-33

Canton, R. (2011) Probation: Working with offenders. Abingdon: Routledge

Cherry, S. (2005) Transforming Behaviour: Pro-social modelling in practice.. Cullompton: Willan Corston, J. (2007) The Corston Report: A review of women with particular vulnerabilities in the Criminal Justice System. London: Home Office

Covington, S. (2008) women and addiction: a trauma-informed approach. Journal of Psychoactive Drugs, SARC Supplement 5, 377-385. 
Deering, J. and Feilzer, M. (2015) Privatising Probation: Is Transforming Rehabilitation the end of the probation ideal? Bristol: Policy Press

Farrant, F. (2006) Knowledge, production and the punishment ethic: The demise of the probation service. Probation Journal, 53, (4), 317-333

Fitzgibbon, W. (2007) 'Risk analysis and the new practitioner: Myth or reality?' Punishment and Society, 9(1), 87-97.

Fitzgibbon, W. (2013) Risk and Privatisation. British Journal of Community Justice, 11, (2/3), 87-90

Goldhill, R. (2015) Reflections on Working with Vulnerable Women: Connecting, Cans of Worms, Closures and Coping. British Journal of Social Work, first published online May 16, 2015 doi:10.1093/bjsw/bcv046 Hart, J. and Collins, K (2014) A 'back to basics' approach to offender supervision: Does working alliance contribute towards success of probation? European Journal of Probation, 6, (2), 112125

Hedderman, C. and Murphy, A. (2015) Bad news for probation? Analysing the newspaper coverage of Transforming Rehabilitation. Probation Journal, 62, (3), 217-233

Heidensohn, F. and Silvestri, M. (2012) Gender and crime. In M. Maguire, R. Morgan and R. Reiner (Eds.) The Oxford Handbook of Criminology. $5^{\text {th }}$ Edition (pp. 336-369). Oxford: Oxford University Press

Henning, K., Jones, A., \& Holdford, R. (2003). Treatment Needs of Women Arrested for Domestic Violence: A Comparison with Male Offenders. Journal of Interpersonal Violence, 18. 839-856.

Hester, M. (2013) Who does what to whom? Gender and domestic violence perpetrators in English police records. European Journal of Criminology, 10(5) 623-637

HM Inspectorate of Probation (2016) Transforming Rehabilitation early implementation 5. Retrieved from: https://www.justiceinspectorates.gov.uk/hmiprobation/wp-content/uploads/sites/5/2016/05/TransformingRehabilitation-5.pdf

Huppatz, K. (2012) Gender Capital at Work: Intersections of femininity, masculinity, class and occupation. London: Palgrave Macmillan

Kadushin, A. and Kadushin, G. (2013) The Social Work Interview [fifth edition]. Chichester: Columbia University Press

Kirton and Guillaume (2015) Employment Relations and Working Conditions in Probation after Transforming Rehabilitation: With a special focus on gender and union effects. Retrieved from:

https://www.napo.org.uk/women-napo

Knight C. and Modi, P. (2014) The use of emotional literacy in work with sexual offenders. Probation Journal, $61(2), 132-147$

Lewis, S. (2014) Learning from success and failure: Deconstructing the working relationship within probation practice and exploring its impact on probationers, using a collaborative approach. Probation Journal, 61, (2), 161-175

Li, H., Desroches, N., Yum, Y., Koehn, C. and Deagle, G. (2007) Asymmetrical Talk between Physicians and Patients: A Quantitative Discourse Analysis. Canadian Journal of Communication, 32, 419-433

Mawby, R.C. \& Worrall, A. (2011) Probation Workers and their Occupational Cultures, Leicester: University of Leicester. (Summary report of ESRC project findings)

Ministry of Justice (MoJ) (2011) The Offender Engagement Programme: An overview from programme director, Martin Copsey. London: Home Office National Probation Service (2001) A New Choreography. London: Home Office

Nellis, M. (2007) Humanising justice: the English Probation Service up to 1972. In L. Gelsthorpe and R. Morgan (Eds.) Handbook of Probation (pp. 25-58). Cullompton: Willan

Ostermann, AC and Comunello da Costa (2012) Gender and professional identity in three institutional settings in Brazil: the case of responses to assessment turns. Pragmatics, 22 (2), 203-230

Pollack, S. (2007) "I'm Just Not Good in Relationships" Victimization discourses and the gendered regulation of criminalized women. Feminist Criminology, 2, (2), 158-174

Raynor, P. and Vanstone, M. Towards a correctional service. In L. Gelsthorpe and R. Morgan (Eds.) Handbook of Probation (pp. 59-89). Cullompton: Willan

Ruch, G. (2005) Relationship-based practice and reflective practice: holistic approaches to contemporary child care social work. Child and Family Social Work, 10, 111-123

Sheehan, R. (2014) Women exiting prison: supporting successful reintegration in a changing penal culture. British Journal of Community Justice, 12 (2), 57-66 
Sorsby, A., Shapland, J., Farrall, S., McNeill, F., Priede, C. and Robinson, G. (2013) Probation staff views of the Skills for Effective Engagement Development (SEED) project. Sheffield: Centre for Criminological Research [http://shef.ac.uk/polopoly_fs/1.293093!/file/probation-staff-views-seed.pdf]. Trotter, C. (1999) Working with Involuntary Clients: a guide to practice. London: Sage

Walby, S. Towers, J. and Francis, B. (2015) Is violence increasing or decreasing?: a new methodology to measure repeat attacks making visible the significance of gender and domestic relations. British Journal of Criminology.

Webster, R. (2016) New probation still undermined by information sharing problems. Retrieved from: http://www.russellwebster.com/new-probation-information-sharing-problems/

Willis, G and Levenson, J. (2016) The relationship between childhood adversity and adult psychosocial outcomes in females who have sexually offended: implications for treatment. Journal of Sexual Aggression, 113

Wooffitt, R. (2005) Conversation Analysis and Discourse Analysis: A Comparative and Critical Introduction. London: Sage

\section{5 words}

